Article

\title{
Functionalization of Silk Fibers by PDGF and Bioceramics for Bone Tissue Regeneration
}

\author{
Michael Wöltje ${ }^{1, * \mathbb{D}}$, Ronny Brünler ${ }^{1}$, Melanie Böbel ${ }^{1}$, Sabrina Ernst ${ }^{2,3}$, Sabine Neuss ${ }^{4,5}$, \\ Dilbar Aibibu ${ }^{1}$ and Chokri Cherif ${ }^{1}$
}

1 Institute of Textile Machinery and High Performance Material Technology, Technische Universität Dresden, 01062 Dresden, Germany; ronny.bruenler@tu-dresden.de (R.B.); melanie.boebel@gmx.de (M.B.); dilbar.aibibu@tu-dresden.de (D.A.); chokri.cherif@tu-dresden.de (C.C.)

2 Institute of Biochemistry and Molecular Biology, RWTH Aachen University, Institute of Biochemistry and Molecular Biology, 52074 Aachen, Germany; sabernst@ukaachen.de

3 Interdisciplinary Center for Clinical Research IZKF, Confocal Microscopy Facility, RWTH Aachen University, 52074 Aachen, Germany

4 Institute of Pathology, RWTH Aachen University, 52074 Aachen, Germany; sneuss-stein@ukaachen.de

5 Helmholtz Institute for Biomedical Engineering - Biointerface Group, RWTH Aachen University, 52074 Aachen, Germany

* Correspondence: michael.woeltje@tu-dresden.de; Tel.: +49-351-46344043

Received: 29 November 2019; Accepted: 17 December 2019; Published: 20 December 2019

\begin{abstract}
Bone regeneration is a complex, well-organized physiological process of bone formation observed during normal fracture healing and involved in continuous remodeling throughout adult life. An ideal medical device for bone regeneration requires interconnected pores within the device to allow for penetration of blood vessels and cells, enabling material biodegradation and bone ingrowth. Additional mandatory characteristics include an excellent resorption rate, a 3D structure similar to natural bone, biocompatibility, and customizability to multiple patient-specific geometries combined with adequate mechanical strength. Therefore, endless silk fibers were spun from native silk solution isolated from silkworm larvae and functionalized with osteoconductive bioceramic materials. In addition, transgenic silkworms were generated to functionalize silk proteins with human platelet-derived growth factor (hPDGF). Both, PDGF-silk and bioceramic modified silk were then assembled into 3D textile implants using an additive manufacturing approach. Textile implants were characterized in terms of porosity, compressive strength, and cyclic load. In addition, osteogenic differentiation of mesenchymal stem cells was evaluated. Silk fiber-based 3D textile implants showed good cytocompatibility and stem cells cultured on bioceramic material functionalized silk implants were differentiating into bone cells. Thus, functionalized 3D interconnected porous textile scaffolds were shown to be promising biomaterials for bone regeneration.
\end{abstract}

Keywords: silk; fiber-based additive manufacturing; bone regeneration

\section{Introduction}

Critical size bone defects can be caused by trauma, tumor resection, reconstructive surgery, congenital malformations, and infections [1]. For the treatment of such bone defects autologous bone grafts are the gold standard therapy [2]. Unfortunately, the limitation of appropriate donor material and the additional surgical intervention to obtain the donor material with the associated co-morbidity at the donor site are limiting this therapeutic approach. Hence, alternative strategies need to be developed to circumvent the shortage of bone tissue. One promising tool in bone defect therapies is tissue engineering. In general, this comprises three steps: (1) design of a three dimensional scaffold 
ideally mimicking the natural environment of damaged tissue, (2) selection of an appropriate cell type, which could be readily isolated, expanded, and differentiated into cells of the target tissue, and (3) implantation of the in vitro generated copy of the target tissue to substitute function in vivo.

A very well-suited scaffold biomaterial for use in bone tissue engineering is silk fibroin because of its good cytocompatibility [3-6] and controllable biodegradability [7-9]. Several studies have successfully used silk scaffolds for bone tissue engineering applications. Besides pure silk scaffolds [10-14], the combination of silk fibroin and ceramic materials such as $\beta$-tricalcium phosphate $(\beta-\mathrm{TCP})[15,16]$ or hydroxyapatite (HA) [17-20] have been investigated extensively. HA represents the largest part of the inorganic component of the human bone [21] and has an osteoconductive effect [22]. B-TCP, on the other hand, has a lower stability but has a higher solubility and is resorbed faster [23,24]. For an ideal scaffold design and a remodeling of the scaffold adapted to the bone metabolism, a balance must be defined between the resorption rate and the new formation of bones [25-27]. Therefore, mixtures of HA and $\beta$-TCP, so-called biphasic calcium phosphates (BCP), have been developed combining the advantages of both materials. Several studies have evaluated and compared bone substitutes with different HA/ $\beta$-TCP ratios to autologous bone or with each other as reviewed extensively by the authors of [28]. However, most commercially available BCPs are composed of a HA/ $\beta$-TCP ratio of $60: 40$ [29]. When silk fibroin was combined with BCP this scaffold type was able to stimulate natural bone formation in a rat model [30].

In addition to scaffold designs mimicking the microenvironment of the bone in terms of biomaterial selection, it also is desirable to functionalize the scaffold with an additional component that promotes growth of bone cells, has a positive effect on the osteogenic differentiation of the immigrated cells, and additionally supports the vascularization of the scaffold. For a successful ingrowth of a tissue engineering construct and the preservation of the function of the implant within the body, a rapid vascularization of the scaffold is absolutely essential [31,32].

Platelet-derived growth factor (PDGF) is a two-chain polypeptide, originally identified in platelets [33,34]. The isoform PDGF-BB can enhance stem cell-based bone regeneration [35-37]. Additionally, PDGF-BB increased callus consolidation when used in combination with a bone-like matrix in a rat distraction ontogenesis model [38]. In combination with a $\beta-\mathrm{TCP} /$ type I bovine collagen matrix PDGF-BB increased fracture repair in diabetic rats [39]. In addition, PDGF-BB delivered with $\beta$-TCP was able to promote ankle fusions and resulted in comparable fusion rates, less pain, and fewer side effects as compared with treatment with autograft [40]. Moreover, PDGF-BB promotes angiogenesis and plays an important role in maintaining the stabilization of newly formed blood vessels $[41,42]$. Furthermore, a recent study suggested that PDGF-BB facilitates mesenchymal stem cell (MSC) based bone regeneration by enhancing the osteogenic and angiogenic abilities of MSC and thus PDGF-BB would be a powerful therapeutic regulator of angiogenesis and osteogenesis during bone formation and repair [43].

Thus, the focus of this work was to develop a suitable scaffold design to enable cellular ingrowth and tissue reconstruction in situ. This includes generation of highly porous three-dimensional textile constructs using silk fibers functionalized with PDGF-BB and HA/ $\beta$-TCP (60:40) as osteoconductive bioceramic material. Functionality in terms of osteogenic differentiation and vascularization using co-cultures of MSC and human umbilical vein endothelial cells (HUVEC) was investigated.

\section{Materials and Methods}

\subsection{Cloning and Virus Generation}

pST-Iex/Bac1-FibLchain was used as a cloning vector. The cloning of that vector has already been explained in detail elsewhere [44]. For cloning of the PDGF-BB expression vector, first, the amino acid sequence for mature human PDGF-BB (UniProt, PRO_0000023372) corresponding to 109 amino acids was transferred into the appropriate DNA sequence. Since mature PDGF-BB is a dimer two of the DNA sequences had to be connected by a linker sequence. Thus, two PDGF DNA sequences were designed: 
PDGFmat1 and PDGFmat2. PDGFmat1 consists of a linker DNA (5'-GGT GGT GGA GGA AGT GGA GGT GGA GGT AGT GGA GGA GGT GGT AGT GGT GGA GGT GGA AGT-3', coding for the amino acid sequence GGGGSGGGGSGGGGSGGGGS; $\mathrm{G}=$ Glycine, $\mathrm{S}=$ Serine) $5^{\prime}$ of the coding sequence for PDGF and an additional restriction enzyme recognition site for PstI. $3^{\prime}$ of the PDGF sequence a XbaI site was included. For PDGFmat 2 the same linker sequence was added $5^{\prime}$ of the PDGF sequence and a XbaI site was added $5^{\prime}$ of the linker. At the $3^{\prime}$ end of the PDGF sequence a NotI site was added. Both DNA sequences were synthesized by MWG (Eurofins MWG Operon, Ebersberg, Germany). After digestion of the sequences of PDGFmat1 and the cloning vector pST-Iex/Bac1-FibLchain with PstI and XbaI (Fermentas, Thermo Fisher Scientific, Schwerte, Germany) the purified PDGFmat1 DNA fragment was ligated into pST-Iex/Bac1-FibLchain. Then, this vector DNA was digested by XbaI and NotI just as the DNA sequence PDGFmat2. Both sequences then were ligated and the resulting vector was named pST-Iex/Bac1-FLC-PDGF. This vector now contained the coding DNA for the fibroin light chain gene linked to the mature PDGF-BB dimeric sequence corresponding to a $55 \mathrm{kDa}$ fusion protein.

Then, the vector DNA pST-Iex/Bac1-FLC-PDGF was used as a template for PCR amplification of the FLC-PDGF cassette using proofreading Pfu DNA Polymerase (Promega, Thermo Fisher Scientific, Schwerte, Germany). After cleaning up the FLC-PDGF PCR product using the Wizard ${ }^{\circledR}$ SV Gel and PCR Clean-Up System (Promega, Thermo Fisher Scientific, Schwerte, Germany), the DNA was cloned into the pFastBac-N-His vector DNA applying the Bac-to-Bac N-His TOPO Cloning Kit (Invitrogen, Thermo Fisher Scientific, Schwerte, Germany) according to the manufacturer's instructions. After transformation, positive clones were verified by sequencing (Eurofins MWG Operon, Ebersberg, Germany) and termed pFastBacNHis-FLC-PDGF. Subsequently, the His-tag was eliminated by cutting pFastBacNHis-FLC-PDGF with RsrII and XbaI (Fermentas, Thermo Fisher Scientific, Schwerte, Germany) and gel extraction of the His-tag free vector DNA by the Wizard ${ }^{\circledR}$ SV Gel and PCR Clean-Up System (Promega, Thermo Fisher Scientific, Schwerte, Germany). The resulting donor plasmid vector DNA pFastBac-FibLchain-PDGF was further used for the generation of recombinant baculoviruses according the Bac-to-Bac ${ }^{\circledR}$ Baculovirus Expression System manual (Invitrogen, Thermo Fisher Scientific, Schwerte, Germany). Viral titers were determined by quantitative PCR using the Fast Advanced Master Mix (Applied Biosystems, Thermo Fisher Scientific, Schwerte, Germany). Harvested virus stocks named AcFLC-PDGF were stored at $4{ }^{\circ} \mathrm{C}$ in the dark until injection.

\subsection{Larval Rearing, Injection, Silk Extraction, Membrane Casting, and Generation of Functionalized Silk Fibers}

Bombyx mori were reared under complete germfree conditions with an artificial diet [45,46]. At the beginning of the fourth molt, larvae were separated from the diet and starved until entering the fifth instar. Then, larvae were infected with AcFLC-PDGF by injecting $100 \mu \mathrm{L}$ of virus, having a titer of $10^{8}$ pfu ml-1, into the third abdominal leg (fifth abdominal segment) using a Microlab 610 Basic Single Syringe Dispenser (Hamilton, Bonaduz, Switzerland) under a laminar hood [47]. Post infection, larvae were returned to germfree conditions and after additional seven days, larvae were dissected and silk was extracted from silk glands as described by Rheinnecker et al. [48].

For membrane generation, silk fibroin solution dissected from silkworm larvae was casted on a glass surface and after evaporation of water the pure silk fibroin membrane was separated from the glass surface.

For generation of functionalized silk fibers, two different approaches were applied. First, the silk solutions isolated from wildtype silkworm larvae's glands and from transgenic silkworm larvae were utilized to spin fibers directly. For the second approach, ceramic materials (HA and $\beta$-TCP) were mixed (60:40) first and then added to the native silk spinning dope, thus the ceramic functionalized silk fibers were produced. By this means, three different types of silk fibers were available for scaffold generation: native silk fibers (Silk), human PDGF-BB functionalized silk fibers (Silk-PDGF) and ceramically functionalized silk fibers (Silk-HA/ $\beta$-TCP). For further experimental investigation of their function in bone generation in vitro, the three fiber types were combined into different fiber-based $3 \mathrm{D}$ porous scaffolds. 


\subsection{SDS PAGE and Western Blotting}

Recombinant growth factor functionalized silk from transgenic silkworms was dissolved in LiSCN $(70 \%)$ over night at room temperature at a concentration of $25 \mathrm{mg} \mathrm{mL}^{-1}$. The concentration of the silk protein was determined using the BCA Protein Assay Kit (Pierce, Thermo Fisher Scientific, Schwerte, Germany). SDS-PAGE was performed using precast gradient polyacrylamide gels $(4 \%-20 \%$, Biostep $\mathrm{GmbH}$, Burkhardtsdorf, Germany), and the separated proteins were stained with Coomassie Brilliant Blue. Blotting of the separated proteins was performed according to the ProtoBlot II AP System manual (Promega, Thermo Fisher Scientific, Schwerte, Germany) and the SNAP i.d. Protein Detection System (Merck, Darmstadt, Germany) using a mouse monoclonal antibody against amino acids 136-190 representing mature PDGF-B of human origin (SC74494, Santa Cruz Biotechnology, Heidelberg, Germany) as primary antibody and an anti-mouse IgG alkaline phosphatase conjugate (Promega, Thermo Fisher Scientific, Schwerte, Germany). Following incubations with the primary antibody and appropriate anti-IgG AP conjugate, Western Blue ${ }^{\circledR}$ Stabilized AP Substrate is applied directly to the blot for color development. Sites of antigen localization turn a dark purple color as a result of alkaline phosphatase activity.

\subsection{Quantification of PDGF Levels Expressed in Transgenic Silkworm Larvae}

Expression of recombinant human PDGF in silkworm larvae was quantified using the Enzyme-linked Immunosorbent Assay (ELISA) principle. First, 96 well Maxisorp ${ }^{\mathrm{TM}}$ high protein-binding flat-bottom 96 well plates (Nunc, Merck, Darmstadt, Germany) were coated either with $45 \mu \mathrm{L}$ per well of silk fibroin isolated from PDGF transgenic silkworm larvae or with $45 \mu \mathrm{L}$ of silk fibroin isolated from unmodified silkworm larvae, serving as controls. The plates were dried at room temperature overnight. Then, $200 \mu \mathrm{L}$ of blocking solution (1\% BSA in PBS) were pipetted onto silk-coated wells. A serial dilution of recombinant human PDGF (PeproTech, Hamburg, Germany) was used to generate a standard curve ranging from $10 \mathrm{ng} \mathrm{ml}-1$ as highest concentration down to $0.15625 \mathrm{ng} \mathrm{mL}^{-1}$. Then, $100 \mu \mathrm{L}$ of each dilution were added to the microplate and the plate was sealed and incubated at room temperature for $2 \mathrm{~h}$. The plate was inverted, whereas only wells containing standards were washed with TBST buffer ( $50 \mathrm{mM}$ TrisHCl,150 $\mathrm{mM} \mathrm{NaCl}, \mathrm{pH}$ 7.6). As a next step, all wells were blocked with blocking solution and the microplate was incubated at room temperature for one hour on a rocker at slow speed. After dumping the well plate, a polyclonal biotinylated rabbit-anti-PDGF antibody (PeproTech, Hamburg, Germany) was applied as a detection antibody, and the plate was incubated slowly for two additional hours on the rocker. Then, the plate was inverted again and all wells were washed four times with TBST buffer. After washing, diluted $(1: 30,000)$ Streptavidin-Horseradish-Peroxidase (HRP) conjugate was pipetted into each well and incubated again for $30 \mathrm{~min}$ on the rocker. Finally, the well plate was washed again five times with TBST and substrate solution for HRP (Thermo Fisher Scientific, Schwerte, Germany) was added. As soon as blue coloration occurred, the reaction was stopped by adding $100 \mu \mathrm{L} 1 \mathrm{M}$ sulfuric acid per well. Then, the color of each well of the microplate was read using a FLUOstar Optima Microplate reader (BMG Labtech, Ortenberg, Germany) at $450 \mathrm{~nm}$ with wavelength correction set at $650 \mathrm{~nm}$. PDGF concentrations in transgenic silk samples were calculated on the basis of the standard curve.

\subsection{Determination of PDGF Bioactivity}

Bioactivity of PDGF-functionalized silk membranes was investigated using cells of the murine fibroblast cell line BALB/c 3T3 clone A31 and the CellTiter-Blue ${ }^{\circledR}$ Cell Viability Assay (Promega, Thermo Fisher Scientific, Schwerte, Germany). Fibroblasts were maintained in DMEM (Dulbecco's Modified Eagle Medium, Sigma-Aldrich, Seelze, Germany) supplemented with 10\% calf serum. For bioactivity assays fibroblast cells were cultured in serum-free DMEM for $24 \mathrm{~h}$ prior to the assay. The 3T3 fibroblasts were seeded in a concentration of 10,000 cells per $32 \mathrm{~mm}^{2}$ on membrane samples of pure silk and PDGF-functionalized silk fibroin, respectively. After $48 \mathrm{~h}$ in cell culture, the medium was aspirated. 
Then, CellTiter-Blue reagent was added according to the manufacturer's manual and the fluorescence signal, which is proportional to cell viability since viable cells convert a redox dye (resazurin) into a fluorescent end product (resorufin). The fluorescent signal was measured at an extinction wavelength of $540 \mathrm{~nm}$ and an emission wavelength of $620 \mathrm{~nm}$ using a FLUOstar Optima Microplate reader (BMG Labtech, Ortenberg, Germany).

\subsection{Simulation-Based Scaffold Design and Additive Manufacturing of Fiber-Based 3D Scaffolds}

For generation of 3D scaffolds with interconnected pores for bone regeneration a fiber-based additive manufacturing technology was applied. The recently developed fiber-based additive manufacturing (FAM) technique was used to combine the different functionalized silk fiber types (Silk-HA/ $\beta$-TCP and Silk-PDGF) as described in details in [49]. In brief, in a preliminary step, the different silk filaments (Silk, Silk-HA/ $\beta$-TCP, Silk-PDGF and Silk-HA/ $\beta$-TCP-PDGF) were cut into short fibers with the length of $1.0 \mathrm{~mm}$. For 3D scaffold generation, FAM processing of silk fibers involves the following repeating steps: (i) robotic deposition of a layer of anisotropic distributed silk fibers of a length of $1.0 \mathrm{~mm}$ and a diameter of $50 \mu \mathrm{m}$, (ii) spatial drop-by-drop dispensing of trifluoroacetic acid (TFA) to temporary dissolve local parts of the fibers within the layer, (iii) deposition of a new fiber layer, which is connected to the previous one by silk fibers glued together at the areas of TFA deposition and simultaneously connecting the present layer with the previous one. During the process, fibers, which are not exposed to TFA serve as support structure and thus allow the realizing of overhangs, undercuts or cavities, similar to powder printing or SLS. The structures provide an interconnected pore network where the pore size is determined by the fiber properties (length and diameter) and can be precisely defined by modeling and simulation using the GeoDict software (Math2Market GmbH, Kaiserslautern, Germany) as shown in Figure 1 and explained in details in [50,51]. For all fiber-based 3D scaffolds (Silk, Silk-HA/ $\beta$-TCP, Silk-PDGF and Silk-HA/ $\beta$-TCP-PDGF) the same model was calculated and used for additive manufacturing by FAM. The morphology of the FAM scaffolds was investigated using a Scanning Electron Microscope (SEM) XL 30 ESEM (Philips Electron Optics, NL).
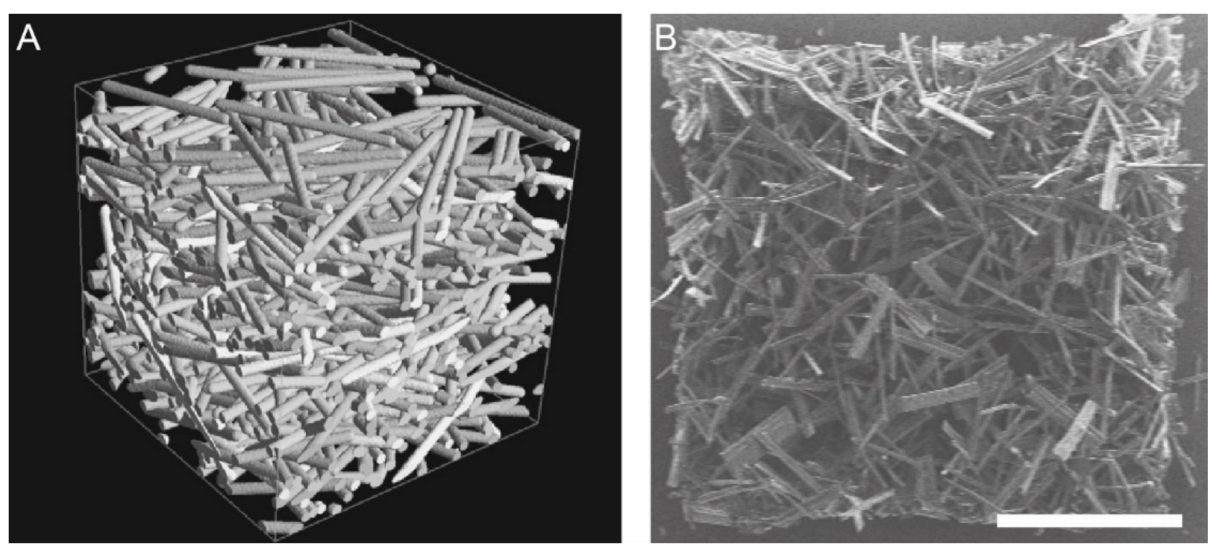

Figure 1. Simulation-based scaffold design and additive manufacturing of silk fiber-based 3D scaffolds. (A) Representative picture of an elementary cell generated using the GeoDict software; (B) Electron microscopy of a 3D silk fiber-based additive manufacturing (FAM) structure manufactured according to the corresponding 3D model structure. The scale bar corresponds to $2 \mathrm{~mm}$.

\subsection{Characterization of Porous Silk Fiber-Based 3D FAM Scaffolds Using Porosimetry and Dynamic Load}

The pore size distribution of the silk fiber-based 3D FAM scaffolds was measured using the liquid displacement technique (Pore Size Meter PSM 165, TOPAS GmbH, Dresden, Germany) following ASTM E1294-89 and ASTM F316-03, which are suitable testing methods for voluminous fabrics such as nonwovens and enable compression-less mounting of the samples. As a capillary constant, 28.6 was used. As a testing fluid, a perfluorocarbon (surface tension $\rho_{1}=16 \mathrm{mN} \mathrm{m}^{-1}$ ), which secures complete 
wetting of the scaffolds without swelling, was used. The sample size for porosity measurements was $5 \mathrm{~mm} \times 5 \mathrm{~mm} \times 3 \mathrm{~mm}$ (length $\times$ width $\times$ height).

Compressive deformation behavior under cyclic load was investigated using a standard material testing machine Zwickiline Z2.5 with $100 \mathrm{~N}$ mount (Zwick/Roell, Ulm, Germany). Specimens in the size of $5 \mathrm{~mm} \times 5 \mathrm{~mm} \times 3 \mathrm{~mm}$ (length $\times$ width $\times$ height) were produced using the FAM technique. Wet scaffolds immersed in phosphate-buffered saline (PBS) were examined. The displacement speed was $0.05 \mathrm{~mm} / \mathrm{s}$. Cyclic testing was performed by repeating ten cycles between deformation rates of $25 \%$ and $60 \%$, respectively.

\subsection{Cell Culture}

Bone marrow derived mesenchymal stromal cells (MSC) were isolated from human femoral heads following informed consent, according to local ethical board approval of the University Hospital, Aachen. MSC were cultured in Mesenpan medium (Pan Biotech, Aidenbach, Germany) supplemented with $2 \%$ Fetal Calf Serum (FCS) and 4 mL LGPS (stem cell medium). Human umbilical vein endothelial cells (HUVEC) were cultured in $\mathrm{EGM}^{\mathrm{TM}}$-2 medium (Promocell, Heidelberg, Germany). In contrast to MSC, the culture flasks for HUVECS were coated with $0.2 \%$ gelatin. Both cell types were incubated at $37^{\circ} \mathrm{C}$ in a humified atmosphere with $5 \% \mathrm{CO}_{2}$. For scaffold seeding cells were counted using a Casy TT Cell Counter + Analyzer according the manufacturers protocol.

\subsection{Analysis of Osteogenic Differentiation by Quantitative Real Time PCR}

Samples were analyzed with the 7300 Real Time PCR System. The expression of the target genes was normalized against the housekeeping GAPDH. The $2-\Delta \Delta$ method was used to analyze the relative expression levels of the target genes [52]. Primers (Eurofins Genomics Germany GmbH, Ebersberg, Germany) used for quantitative Real Time PCR are shown in Table 1.

Table 1. Primer sequences for amplification of marker genes for bone differentiation.

\begin{tabular}{ccc}
\hline Marker Gene & Sequence & Fragment Size [bp] \\
\hline ALP Fwd & 5'-CAG GCC CAT TGG CAT AGA G-3' & 89 \\
ALP Rev & 5'-CCG TGG CAA CTC TAT CTT TGG-3' & \\
BMP2 Fwd & 5'-ACA AAC AGC GGA AAC GCC T-3' & 74 \\
BMP2 Rev & 5'-CCA CCC CAC GTC ACT GAA G-3' & \\
Runx2 Fwd & 5'-GCA AGG TTC AAC GATCTG AGA TT-3' & 74 \\
Runx2 Rev & 5'-AAG ACG GTT ATG GTC AAG GTG AA-3' & \\
GAPDH Fwd & 5'-GAA GGT GAA GGT CGG AGT CA-3' & \multirow{2}{*}{109} \\
GAPDH Rev & 5'-AAT GAA GGG GTC ATT GAT GG-3' & \\
\hline
\end{tabular}

\subsection{Confocal Laser Scanning Microscopy (CLSM) Analysis of Capilary Network Formation}

Confocal laser scanning microscopy (CLSM) was used to gain high resolution images of MSC and HUVEC on silk fiber-based scaffolds. For CLSM analysis cells were stained with the endothelial cell specific marker CD31, with the stromal cytoskeleton marker vimentin and with the nuclear counterstain DAPI (4',6- diamidino-2-phenylindole).

After 20 days in culture, cell seeded scaffolds were washed with PBS. Then, the cells were fixed in $4 \%$ formalin for $10 \mathrm{~min}$ at room temperature. Scaffolds were washed twice with PBS again to remove all traces of formalin. For permeabilization of cells $0.5 \%$ Triton $^{\mathrm{TM}} \mathrm{X}-100$ was added for $8 \mathrm{~min}$ at room temperature. After removal of Triton ${ }^{\mathrm{TM}} \mathrm{X}-100$ samples were washed twice with PBS again. For staining of CD31 a murine monoclonal antibody (Sigma-Aldrich, Seelze, Germany, dilution 1:400 in PBS with $3 \%$ BSA) was used and for vimentin staining a rabbit monoclonal antibody (abcam, Cambridge, United Kingdom, dilution 1:200 in PBS with 3\% BSA) was applied. After antibody incubation for three hours, samples were washed twice with PBS containing 3\% BSA for $5 \mathrm{~min}$, followed by incubation with the secondary antibodies (Alexa Fluor ${ }^{\circledR} 488$ goat anti-rabbit and Alexa Fluor ${ }^{\circledR} 594$ goat anti-mouse., 
dilution 1:400 in PBS with 3\% BSA, both from Life Technologies, Darmstadt, Germany). Finally, samples were washed three times (PBS/3\% BSA) for $5 \mathrm{~min}$, followed by incubation with DAPI (dilution 1:1000) for $5 \mathrm{~min}$ at room temperature. Then, scaffolds were transferred into $\mu$-Slide wells, fixed with mounting medium and analyzed with a $40 \times$ objective. Z-stacks were merged of $3 \times 3$ single images and processed with the maximum intensity projection tool, of the ZEN2009 Software. The resulting z-stack images covered a sample thickness of $50 \mu \mathrm{m}$ to $70 \mu \mathrm{m}$ each.

\subsection{Statistical Evaluation}

Statistical analysis was conducted using one-way analysis of variance (ANOVA) followed by Student's $t$-test (independent, two sided). Differences were considered significant for $p<0.05$. All data are expressed as means \pm standard error of the mean (SEM).

\section{Results}

\subsection{Expression of Human Recombinant PDGF-Functionalized Silk Fibroin in Transgenic Silkworm Larvae}

Transgenic silkworm larvae expressing human PDGF as a fusion protein within the silk gland were successfully generated, as confirmed by western blotting experiments (Figure 2). Samples of silk fibroin isolated from four different PDGF transgenic silkworm batches were separated by polyacrylamide gel electrophoresis (PAGE), and the presence of human PDGF within the silk fibroin was detected by western blotting using an antibody against human PDGF.

The detected fusion protein had a total molecular size of ca. $55 \mathrm{kDa}$ (as visible in lane 1 to 4 of Figure 2), which results from combining the PDGF molecule with the fibroin light chain protein. Silk from unmodified silkworm larvae (wildtype silk, Figure 2, lane C) did not show a signal for human PDGF. Each of the four batches was produced from independent injection cycles with baculovirus particles. Silk fibroin of at least 50 silkworm larvae was pooled per batch. The yield of presented human PDGF per batch was determined to be approximately $0.36 \mathrm{ng} / \mathrm{mL}$, which represents $0.11 \mathrm{ng} / \mathrm{cm}^{2}$ silk membrane surface area, using enzyme-linked immunosorbent assay (ELISA; mean value of 4 batches silk fibroin isolated from transgenic silkworm larvae).

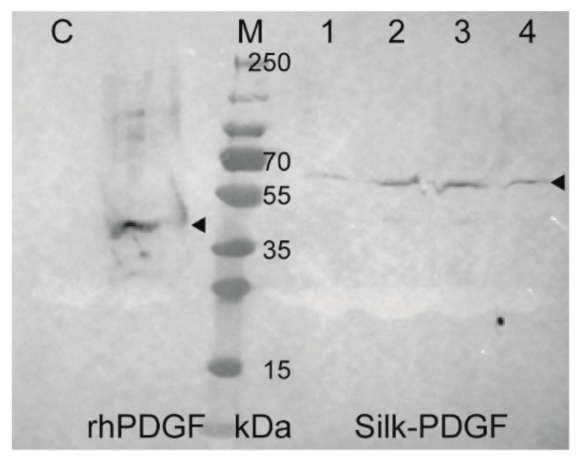

Figure 2. Western blot analysis of platelet-derived growth factor (PDGF) presenting silk membranes. Silk fibroin membranes from untreated wildtype silkworm larvae (C) and four different batches of transgenic FLC-PDGF-BB silkworm larvae (Silk-PDGF, lane 1-4) were dissolved in LiSCN and $125 \mu \mathrm{g}$ of each silk solution was loaded on a precast gradient polyacrylamide gel (4\%-20\%, Biostep GmbH, Burkhardtsdorf, Germany). In addition, 20 ng recombinant human PDGF-BB (PeproTech, Hamburg, Germany) was loaded as positive control (rhPDGF). PageRuler ${ }^{\mathrm{TM}}$ Plus Prestained Ladder (10 to $250 \mathrm{kDa}$, Thermo Fisher Scientific, Schwerte, Germany) was used as a marker (M). Detection of human PDGF was performed using a mouse monoclonal antibody against amino acids 136-190 of PDGF of human origin (Santa Cruz Biotechnology, Heidelberg, Germany). PDGF positive signals are marked by an arrowhead. 


\subsection{Bioactivity of Human PDGF-Functionalized Silk Fibroin Membranes}

In order to prove the bioactivity of harvested PDGF-functionalized silk fibroin fusion proteins, cell culture assays using mouse fibroblasts were performed. Silk membranes cast from wildtype silk fibroin (silk) and PDGF-functionalized silk fibroin (silk-PDGF) were seeded with BALB/c 3T3 clone A31 (3T3) fibroblasts. Cell viability was monitored over $48 \mathrm{~h}$ and calculated as $\mathrm{x}$-fold increase compared to $3 \mathrm{~T} 3$ cells cultured in parallel on wildtype silk fibroin membranes. As revealed in Figure 3, the number of fibroblasts cultured on silk-PDGF was only slightly higher (1.3-fold) than on wildtype silk but the difference was highly significant $(p<0.001)$ thus proving the bioactivity of the produced PDGF-functionalized silk fibroin fusion protein.

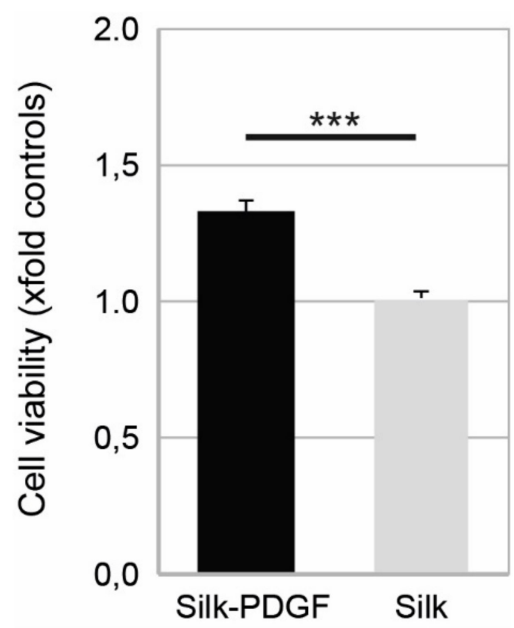

Figure 3. Bioactivity of human recombinant PDGF-functionalized silk fibroin membranes. Silk isolated from human PDGF transgenic silkworm larvae was used to cast PDGF-presenting silk membranes (black bar) and unmodified wildtype silk was used as control (grey bar). Membranes were seeded using BALB/c 3 T3 clone A31 fibroblasts. After $48 \mathrm{~h}$ in culture, BALB/c 3T3 cell viability was quantified using a cell viability assay and viability values were expressed as $\mathrm{x}$-fold of viability of fibroblast cells cultured on standard silk membranes (grey bar). All experiments were performed with five independent batches of control silk and transgenic silk, respectively, in quintuplicates $\left.{ }^{* * *}: \mathrm{p} \leq 0.001\right)$.

\subsection{Characterization of Silk Fiber-Derived 3D Porous FAM Scaffolds}

Silk 3D scaffolds were modeled and produced with FAM using 4 different compositions: Silk, Silk-HA/B-TCP, Silk-PDGF and Silk-HA/B-TCP-PDGF. To ensure ingrowth of mesenchymal stem cells, bone precursor cells and vascularization into the porous three-dimensional FAM scaffold interconnectivity and porosity is mandatory. Thus, SEM pictures of all four FAM scaffold types were analyzed (Figure 4). All four types of 3D porous scaffolds show the same interconnectivity, porosity and an even distribution of pore sizes. Furthermore, the surface roughness is not significantly different between the three scaffold types (compare detail picture, Figure 4). In addition, the combination of the three fiber types in the combined scaffold (Figure 4D) shows a very good distribution and homogeneity of the different types of fibers during the fabrication of the 3D FAM scaffolds. 


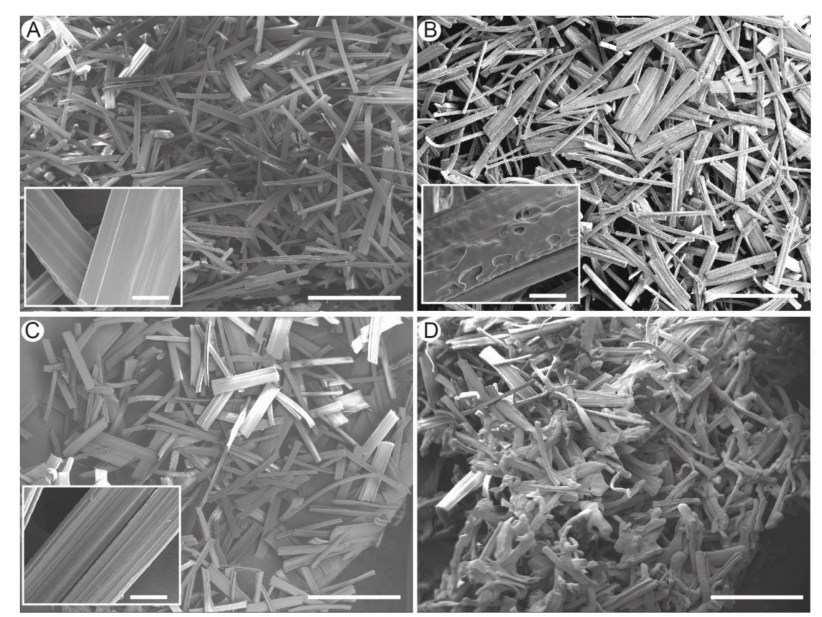

Figure 4. SEM images of the different FAM scaffolds. Images present the surface characteristics and pore size of the Silk (A), Silk-HA/ $\beta$-TCP (B), Silk-PDGF (C) and Silk-HA/ $\beta$-TCP/PDGF (D) 3D scaffolds, respectively (scale bar: $1 \mathrm{~mm}$ and $50 \mu \mathrm{m}$ for inserts).

For quantification of porosity and pore size distribution, 3D FAM scaffolds were analyzed using the liquid displacement technique. Since the SEM images did not reveal any obvious differences in porosity, the quantification of pore sizes and pore size distribution was carried out exemplarily on silk scaffolds without any modification. As shown in Figure 5, the constant pore size distribution ranges from $23 \mu \mathrm{m}$ to $207 \mu \mathrm{m}$ with a mean pore size of $98.4 \mu \mathrm{m}$ and an average porosity of $87 \%$.

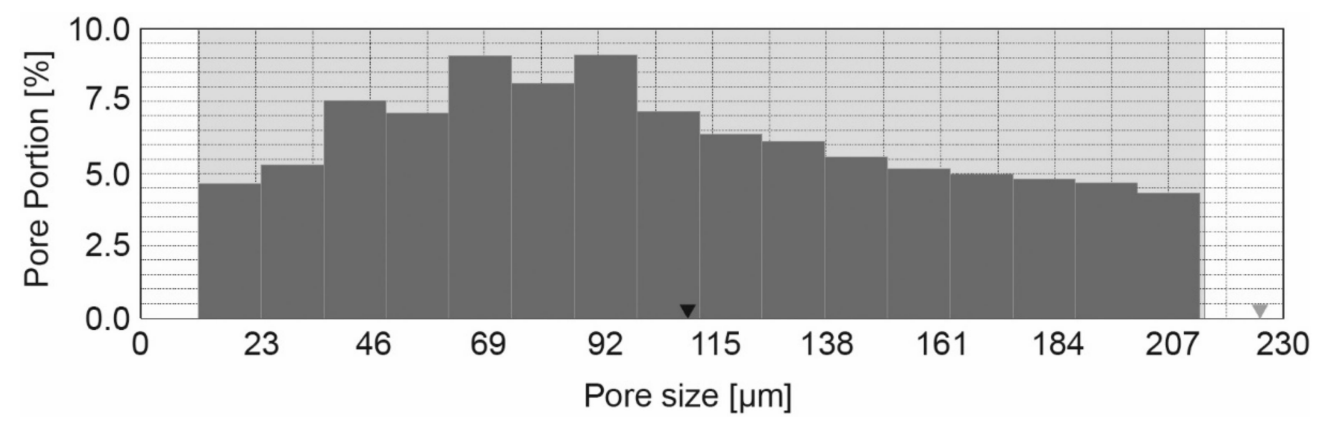

Figure 5. Pore size distribution in 3D FAM scaffolds (representative graph). The pore size is given in $\mu \mathrm{m}$ and the according pore portion in $\%$. The mean pore size is shown by the black triangle $(\mathrm{n}=5)$.

Mechanical properties such as compressive strength and the compressive deformation behavior are important for the design of scaffolds to be used in bone regeneration. Therefore, compressive deformation behavior under cyclic load was investigated. As shown in Figure 6, the compressive load values for the HA/ $\beta$-TCP functionalized silk fiber-derived scaffolds show an average of $93 \mathrm{KPa}$ after one cycle and $82 \mathrm{Kpa}$ after 10 cycles. This is a reduction by $12.3 \%$ for the scaffold type with the highest amount of ceramic material. The scaffolds composed of Silk-HA/ $\beta$-TCP/PDGF exhibit an average compressive load of $74 \mathrm{Kpa}$ after one and $52 \mathrm{Kpa}$ after 10 cycles, which means a reduction by $29.3 \%$. The FAM scaffolds without any ceramic component showed a distinct reduction in compressive load compared to those scaffolds with ceramic ingredients. The average compressive load was around $43 \mathrm{Kpa}$ after one compression cycle and around $21 \mathrm{Kpa}$ after 10 cycles. This corresponds to a reduction by 52.7 percent. This means that a higher content of ceramic materials with in the scaffold results in a higher compressive load bearing capacity. 


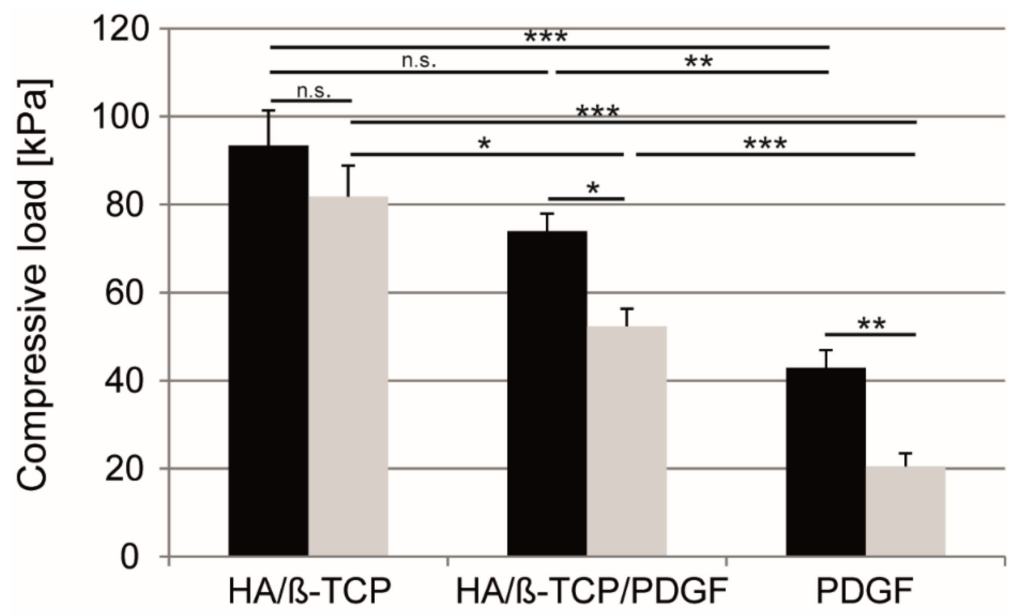

Functionalization of silk fibers

Figure 6. Characterization of the compressive load of silk derived FAM scaffolds. The average compressive load of wet FAM scaffolds composed of fibers from Silk-HA/ $\beta$-TCP, Silk-HA/ $\beta$-TCP/PDGF, and Silk-PDGF after one cycle (black bars) and after ten cycles (grey bars) within $60 \%$ and $25 \%$ offset yield strength are shown $(\mathrm{n}=5)$. Significant differences are shown (n.s.: no significance; ${ }^{*}: p \leq 0.05 ;{ }^{* *}$ : $\left.p \leq 0.01 ;{ }^{* * *}: p \leq 0.001\right)$.

\subsection{Cell Attachment and Growth on silk FAM Scaffolds}

The silk 3D FAM scaffolds enable MSC attachment and growth (Figure 7). Green fluorescence (vimentin staining) demonstrates that on all scaffold types MSC attached well und covered the fiber surfaces. Furthermore, MSC already started to bridge the open pores after 20 days of culture. In addition, red fluorescence signals (CD31 staining) show a capillary-like fibrillar network build from HUVEC through all scaffold types. These network structures are not limited on single fibers but even penetrate the whole 3D structures. However, there was no difference neither in the colonization of silk fibers with MSC (green fluorescence) nor in the formation of HUVEC networks (red fluorescence) between the different scaffolds from various functionalized silk fiber types (compare Figure 7A-D). At least the combined silk scaffold composed of all types of functionalized silk fibers (Silk-HA/ $\beta$-TCP/PDGF) seems to induce an increased network formation of HUVEC (Figure 7D).
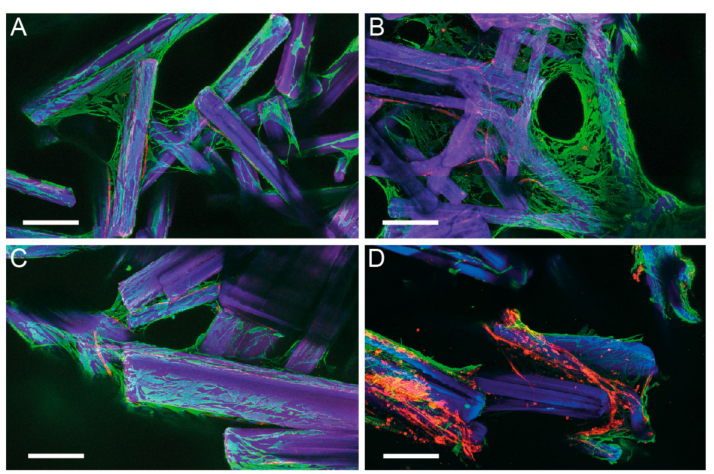

Figure 7. Confocal laser scanning microscopy (CLSM) images of mesenchymal stem cell (MSC) and human umbilical vein endothelial cells (HUVEC) co-cultured on different silk scaffolds. Images present growth of MSC and HUVEC on Silk (A), Silk-HA/ $\beta$-TCP (B), Silk-PDGF (C) and Silk-HA/ $\beta$-TCP/PDGF (D) 3D scaffolds, respectively. MSC were stained for vimentin (green) and HUVEC for CD31 (red). Due to auto-fluorescence silk fibers appear violet. (scale bar: $200 \mu \mathrm{m}$ ). 


\subsection{Osteogenic Differentiation}

In order to analyze osteogenic differentiation of MSC in monoculture or in co-culture with HUVEC on the three different silk scaffold types for 20 days, gene expression of marker genes for osteogenic differentiation (ALP, BMP-2, and Runx2) was quantified using Real Time PCR. Gene expression data of MSC cultured in mono or in co-culture with HUVEC on the three different scaffolds (Silk-PDGF, Silk-HA/ $\beta$-TCP, Silk-HA/ $\beta$-TCP/PDGF) was normalized to gene expression of MSC cultured on tissue culture plastics. As demonstrated in Figure 8, MSC showed no significantly higher gene expression of the three marker genes when MSC were cultured in mono- or in co-culture with HUVECS on Silk-PDGF scaffolds or Silk HA/ $\beta$-TCP scaffolds. Nevertheless, when Silk-HA/ $\beta$-TCP was combined with Silk-PDGF in one single FAM scaffold a significant increase of gene expression for ALP and BMP-2 in MSC co-cultured with HUVEC was detected. However, in monoculture of MSC on the Silk $\mathrm{HA} / \beta-\mathrm{TCP} / \mathrm{PDGF}$ scaffold an obvious increase of gene expression for ALP and BMP-2 was detectable but this was not statistically significant. In this context, it is important to note that no osteogenic differentiation inducing chemicals such as sodium $\beta$-glycerophosphate, dexamethasone, or 1-ascorbic acid 2-phosphate had been added to the culture medium. Thus, these results indicate an osteoinductive effect of the silk scaffold type combining PDGF with the ceramic component.

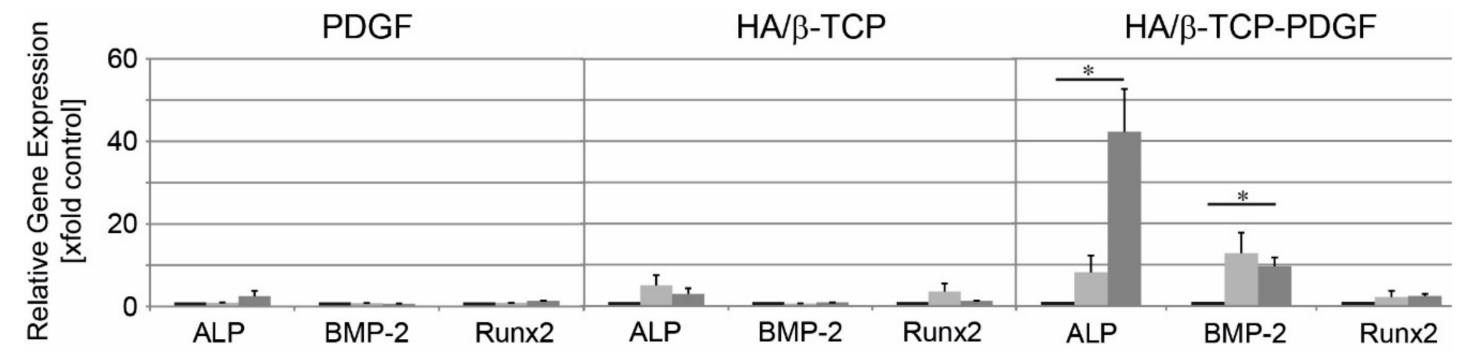

Figure 8. Relative gene expression of osteogenic marker genes. Differentiation of MSC towards an osteoblast phenotype was analyzed by quantification of gene expression of three marker genes for bone differentiation (ALP, BMP-2, Runx2). Marker gene expression is shown as $\mathrm{x}$-fold of controls (MSC on tissue culture plastics, black bars) for MSC alone (light grey bars) or for MSC co-cultured with HUVEC on the different scaffold types (dark grey bars). All Real Time PCR experiments were performed in duplicates. Experiments were performed with MSC isolated from three different human donors $(*: p \leq 0.05)$.

\section{Discussion}

The main advantage of textile implants is the particularly high surface to volume ratio with large surfaces for functionalization. Fiber-based textile implants such as FAM structures show adjustable high porosity and interconnected pores. Additionally, through combination of different fiber types and materials composite scaffolds for regenerative medicine could be easily realized. Thus, in the present study a scaffold for bone regeneration was developed, which is composed of PDGF-BB functionalized silk fibers and HA/ $\beta$-TCP functionalized silk fibers. The two functionalized fiber types were combined in a 3D porous scaffold with an interconnected pore structure by fiber-based additive manufacturing (FAM). The aim of the study was to investigate the potential of this new scaffold type to induce ingrowth of new vascular structures and osteogenic differentiation in vitro.

For functionalization of silk fibers with recombinant PDGF-BB transgenic silkworm larvae producing the growth factor together with the silk fibroin molecules within the silk gland were successfully developed. In the presented approach PDGF-BB was covalently coupled to the silk, hence generating a silk fiber, which presents the growth factor on the surface of the silk fiber without any chemical treatment or modification, also recently shown for epidermal growth factor (EGF) in a wound healing model in vitro [44]. The rationale for this approach was based on studies demonstrating that covalently coupled growth factors cannot be internalized after activation of the corresponding receptor. 
This prevents consumption of the growth factor and down-regulation of the receptor $[53,54]$. Thus, the tethering of growth factors to biomaterial surfaces increases the biological stability of growth factors [52] and finally, much lower concentrations of growth factors are required to induce biological effects, which in turn minimizes negative side effects. Consequently, even small quantities of PDGF-BB tethered to silk materials are sufficient to induce an effect as demonstrated by a significant increase of cell viability of BALB/c 3T3 cells after culture for $48 \mathrm{~h}$ on silk membranes casted from silk fibroin isolated from PDGF-BB transgenic silkworm larvae.

Besides PDGF-BB functionalized silk fibers, an additional type of fiber was spun, which has been modified by HA/ $\beta$-TCP in a ratio of $60 / 40$ to mimic the bone environment. Using the FAM technology biocompatible HA/ $\beta$-TCP-embedded silk scaffolds were manufactured while maintaining pore size and interconnectivity. The adjustable open porosity of $87 \%$ of all scaffold types in combination with a high interconnectivity was realized according the trabecular bone porosity for human mandibular condyles, that was shown to range from $72.6 \%$ to $87.4 \%$ [55]. Furthermore, the pore size distribution between $23 \mu \mathrm{m}$ and $207 \mu \mathrm{m}$ with a mean pore size of $98.4 \mu \mathrm{m}$ is in good accordance with several studies, which associated a high degree of interconnectivity and pore sizes ranging from 100 to $300 \mu \mathrm{m}$ with a positive effect on bone tissue formation [56-59].

The functionalization of silk fibers with $\mathrm{HA} / \beta-\mathrm{TCP}$ altered scaffold surface, increased surface roughness and the stiffness of unseeded scaffolds. The scaffolds manufactured from silk-HA/ $\beta$-TCP showed the highest compressive strength during cyclic compression analysis of $82 \mathrm{KPa}$ compared to those scaffolds consisting of a combination of all three different silk fiber types (silk-HA/ $/$-TCP/PDGF-BB) of $52 \mathrm{KPa}$ or silk-PDGF-BB with the lowest value of $21 \mathrm{KPa}$. The loss of stability after compressive load application between the first and the tenth cycle of compression in all three scaffolds investigated is due to structural damage of individual short fibers and the breakage of joints between the various short fibers. Nevertheless, it is obvious that the integration of ceramic materials such as the mixture of HA/ $\beta$-TCP results in a considerable increase in load absorption correlating with the quantity of ceramically functionalized silk fibers used for scaffold assembly by FAM. However, the recorded stability against compressive load is far below those values for maximal compressive strength before failure for human bone. Regarding anatomic site, these values can vary between $2 \mathrm{MPa}$ for vertebral trabecular bone, $7 \mathrm{MPa}$ for distal femoral bone and 0.22 to $10 \mathrm{MPa}$ for mandibular trabecular bone [60-62]. The compressive strength could be adjusted by modifying the manufacturing parameters during the FAM process by simply increasing the proportions of ceramic functionalized fibers. This can be easily achieved while maintaining constant porosity by reducing the number of the other fiber types within the scaffold. In this context, porosity needs to be kept constant because the mechanical strength conflicts with the porosity. Excessive porosity will inevitably lead to a decrease in compressive strength [63-67].

A co-culture system of MSC and HUVEC cells was used to investigate the influence of scaffold geometry and the different functionalized silk fibers alone and in combination (silk, silk-HA/ $\beta-\mathrm{TCP}$, silk-PDGF-BB, and silk-HA/ $\beta-T C P / P D G F-B B)$. Both cells types grew well on all silk scaffolds and after 20 days in culture MSC did not only grow on fiber surfaces, but had already started to close the pores. A co-culture of human HUVEC and MSC enables investigation of both angiogenesis (formation of vascular structures by HUVEC) and osteogenesis (differentiation of MSC into an osteogenic phenotype) induced by growth factor treatment and ceramic functionalization strategies of scaffolds. In all four investigated scaffold types, CD31 positive staining showed fibrillary HUVEC extensions forming a network. This increase in endothelial network formation following addition of cells of the endothelial lineages into osteoprogenitor cell cultures has been described before by several other groups [68-72]. Unfortunately, no increased formation of endothelial network structures could be observed in silk scaffolds functionalized by PDGF-BB. Probably, the co-culture effect of HUVEC and MSC overwrote PDGF signaling induced by the surface presentation of PDGF-BB. This is in strong accordance to findings of Unger et. al., which demonstrated a supportive effect of nonwoven silk fibroin nets on endothelial cell growth and thus a strong potential for angiogenesis [73]. Further, co-culture of 
endothelial and primary osteoblasts within silk fibroin scaffolds form organized and prevascular structures [74]. Nevertheless, it could be possible that locations within the scaffolds with PDGF-BB functionalized fibers have an influence on orientation of the growing vascular network. This is an interesting aspect, which needs further investigations. This would also offer the possibility to guide pre-vascularization events within a scaffold by targeting the delivery of PDGF-BB modified silk fibers to specific location within the 3D scaffold structure-an approach which is easily implementable with the FAM technology.

Although no bone differentiation inducing substances such as sodium $\beta$-glycerophosphate, dexamethasone, or 1-ascorbic acid 2-phosphate had been added to the culture medium, osteogenic differentiation of MSC was detected by molecular biological analysis. Osteogenic marker genes for ALP and BMP-2 showed a significant higher expression if cells were co-cultured on scaffolds assembled from silk-HA/ $\beta$-TCP/PDGF-BB fibers. Neither on scaffolds from silk-PDGF-BB nor from ceramically functionalized silk-HA/ $\beta$-TCP fibers any statistically significant alteration of marker gene expression was detectable. Thus, three factors seem to play an important role in induction of osteogenic differentiation of MSC without chemical inductors of osteogenesis: i) presentation of PDGF-BB, ii) a HA/ $\beta$-TCP modified environment, and iii) the co-culture of MSC and HUVEC cells. As reviewed in detail by Farokhi et. al. [75] silk-based scaffolds provide suitable substrates for supporting the proliferation and adhesion of MSC [76,77]. Furthermore, silk protein provoked the upregulation of some osteoblast differentiation markers (e.g., ALP, osteorix and Runx2) by inhibiting the Notch signaling pathway [78]. The inhibition of osteogenic differentiation by Notch signaling is triggered by Hes and Hey proteins, which can suppress Runx2 activity through physical interaction [79] as also observed in the presented study. Runx 2 expression on silk-HA/ $\beta$-TCP/PDGF-BB is not altered whereas ALP and BMP-2 are upregulated. Also, Zhang et al. demonstrated that overexpression of PDGF-BB in MSC increased osteogenic differentiation while inhibiting adipogenic differentiation via the ERK1/2 signaling pathway. PDGF-BB secreted by the PDGF-B modified MSC significantly enhanced the migration and angiogenesis of vascular endothelial cells via the PI3K/AKT and ERK1/2 signaling pathways [43].

In conclusion, the combination of silk and ceramic functionalization together with an open porous interconnected textile structure manufactured by applying the FAM technology induces a fibrillar network of endothelial cells. PDGF-BB functionalization in combination with bioceramic functionalization by HA/ $\beta$-TCP induced osteogenic differentiation of human mesenchymal stem cells without any additional induction media. Consequently, the presented approach might offer a new route for generation of functionalized scaffolds for faster ingrowth of new bone after implantation and thus faster regeneration of bone defects.

Author Contributions: Conceptualization, M.W., S.N. and D.A.; Methodology, M.B., R.B., M.W., S.N. and D.A.; Validation, M.W., S.N. and D.A.; Formal analysis, M.W.; Investigation, M.B., R.B., S.E., S.N.; Writing-original draft preparation, M.W.; Writing-review and editing, M.W., M.B., R.B., S.N., D.A., C.C.; Visualization, M.W., S.N., R.B..; Supervision, M.W., S.N., D.A., C.C.; Project administration, M.W., S.N., D.A.; Funding acquisition, M.W., S.N., C.C. All authors have read and agreed to the published version of the manuscript.

Funding: This research project (KF 2340102AJ3) was funded within "The Central Innovation Programme for SMEs" (ZIM) from funds of the Federal Ministry for Economic Affairs and Energy (BMWi), following a decision of the German Bundestag.

Conflicts of Interest: The authors declare no conflict of interest.

\section{References}

1. Dimitriou, R.; Jones, E.; McGonagle, D.; Giannoudis, P.V. Bone regeneration: Current concepts and future directions. BMC Med. 2011, 9, 66. [CrossRef] [PubMed]

2. Lichte, P.; Pape, H.C.; Pufe, T.; Kobbe, P.; Fischer, H. Scaffolds for bone healing: Concepts, materials and evidence. Injury 2011, 42, 569-573. [CrossRef] [PubMed] 
3. Uebersax, L.; Apfel, T.; Nuss, K.M.R.; Vogt, R.; Kim, H.Y.; Meinel, L.; Kaplan, D.L.; Auer, J.A.; Merkle, H.P.; von Rechenberg, B. Biocompatibility and osteoconduction of macroporous silk fibroin implants in cortical defects in sheep. Eur. J. Pharm. Biopharm. 2013, 85, 107-118. [CrossRef] [PubMed]

4. Ghaznavi, A.M.; Kokai, L.E.; Lovett, M.L.; Kaplan, D.L.; Marra, K.G. Silk fibroin conduits: A cellular and functional assessment of peripheral nerve repair. Ann. Plast. Surg. 2011, 66, 273-279. [CrossRef]

5. Kim, K.-H.; Jeong, L.; Park, H.-N.; Shin, S.-Y.; Park, W.-H.; Lee, S.-C.; Kim, T.-I.; Park, Y.-J.; Seol, Y.-J.; Lee, Y.-M.; et al. Biological efficacy of silk fibroin nanofiber membranes for guided bone regeneration. J. Biotechnol. 2005, 120, 327-339. [CrossRef]

6. Altman, G.H.; Diaz, F.; Jakuba, C.; Calabro, T.; Horan, R.L.; Chen, J.; Lu, H.; Richmond, J.; Kaplan, D.L. Silk-based biomaterials. Biomaterials 2003, 24, 401-416. [CrossRef]

7. Gross, J.E.; Horan, R.L.; Gaylord, M.; Olsen, R.E.; McGill, L.D.; García-López, J.M.; Biber, K.; Barnico, K.; Toponarski, I.; Altman, G. An evaluation of SERI surgical scaffold for soft-tissue support and repair in an ovine model of two-stage breast reconstruction. Plast. Reconstr. Surg. 2014, 134, 700e-704e. [CrossRef]

8. Shang, K.; Rnjak-Kovacina, J.; Lin, Y.; Hayden, R.S.; Tao, H.; Kaplan, D.L. Accelerated In Vitro Degradation of Optically Clear Low $\beta$-Sheet Silk Films by Enzyme-Mediated Pretreatment. Transl. Vis. Sci. Technol. 2013, 2, 2. [CrossRef]

9. Wang, Y.; Rudym, D.D.; Walsh, A.; Abrahamsen, L.; Kim, H.-J.; Kim, H.S.; Kirker-Head, C.; Kaplan, D.L. In vivo degradation of three-dimensional silk fibroin scaffolds. Biomaterials 2008, 29, 3415-3428. [CrossRef]

10. Qian, J.; Suo, A.; Jin, X.; Xu, W.; Xu, M. Preparation and in vitro characterization of biomorphic silk fibroin scaffolds for bone tissue engineering. J. Biomed. Mater. Res. A 2014, 102, 2961-2971. [CrossRef]

11. Meinel, L.; Hofmann, S.; Betz, O.; Fajardo, R.; Merkle, H.P.; Langer, R.; Evans, C.H.; Vunjak-Novakovic, G.; Kaplan, D.L. Osteogenesis by human mesenchymal stem cells cultured on silk biomaterials: Comparison of adenovirus mediated gene transfer and protein delivery of BMP-2. Biomaterials 2006, 27, 4993-5002. [CrossRef] [PubMed]

12. Hofmann, S.; Hagenmuller, H.; Koch, A.M.; Muller, R.; Vunjak-Novakovic, G.; Kaplan, D.L.; Merkle, H.P.; Meinel, L. Control of in vitro tissue-engineered bone-like structures using human mesenchymal stem cells and porous silk scaffolds. Biomaterials 2007, 28, 1152-1162. [CrossRef] [PubMed]

13. Kim, H.J.; Kim, U.-J.; Leisk, G.G.; Bayan, C.; Georgakoudi, I.; Kaplan, D.L. Bone regeneration on macroporous aqueous-derived silk 3-D scaffolds. Macromol. Biosci. 2007, 7, 643-655. [CrossRef] [PubMed]

14. Meinel, L.; Fajardo, R.; Hofmann, S.; Langer, R.; Chen, J.; Snyder, B.; Vunjak-Novakovic, G.; Kaplan, D. Silk implants for the healing of critical size bone defects. Bone 2005, 37, 688-698. [CrossRef] [PubMed]

15. Lee, D.H.; Tripathy, N.; Shin, J.H.; Song, J.E.; Cha, J.G.; Min, K.D.; Park, C.H.; Khang, G. Enhanced osteogenesis of beta-tricalcium phosphate reinforced silk fibroin scaffold for bone tissue biofabrication. Int. J. Biol. Macromol. 2016, 95, 14-23. [CrossRef]

16. Pina, S.; Canadas, R.F.; Jiménez, G.; Perán, M.; Marchal, J.A.; Reis, R.L.; Oliveira, J.M. Biofunctional Ionic-Doped Calcium Phosphates: Silk Fibroin Composites for Bone Tissue Engineering Scaffolding. Cells Tissues Organs (Print) 2017, 204, 150-163. [CrossRef]

17. Ko, E.; Lee, J.S.; Kim, H.; Yang, S.Y.; Yang, D.; Yang, K.; Lee, J.; Shin, J.; Yang, H.S.; Ryu, W.; et al. Electrospun Silk Fibroin Nanofibrous Scaffolds with Two-Stage Hydroxyapatite Functionalization for Enhancing the Osteogenic Differentiation of Human Adipose-Derived Mesenchymal Stem Cells. ACS Appl. Mater. Interfaces 2018, 10, 7614-7625. [CrossRef]

18. Wang, G.; Yang, H.; Li, M.; Lu, S.; Chen, X.; Cai, X. The use of silk fibroin/hydroxyapatite composite co-cultured with rabbit bone-marrow stromal cells in the healing of a segmental bone defect. J. Bone Jt. Surg. Br. 2010, 92, 320-325. [CrossRef]

19. Kim, H.J.; Kim, U.-J.; Kim, H.S.; Li, C.; Wada, M.; Leisk, G.G.; Kaplan, D.L. Bone tissue engineering with premineralized silk scaffolds. Bone 2008, 42, 1226-1234. [CrossRef]

20. Bhumiratana, S.; Grayson, W.L.; Castaneda, A.; Rockwood, D.N.; Gil, E.S.; Kaplan, D.L.; Vunjak-Novakovic, G. Nucleation and growth of mineralized bone matrix on silk-hydroxyapatite composite scaffolds. Biomaterials 2011, 32, 2812-2820. [CrossRef] 
21. Fratzl, P.; Gupta, H.S.; Paschalis, E.P.; Roschger, P. Structure and mechanical quality of the collagen-mineral nano-composite in bone. J. Mater. Chem. 2004, 14, 2115-2123. [CrossRef]

22. Ogata, K.; Imazato, S.; Ehara, A.; Ebisu, S.; Kinomoto, Y.; Nakano, T.; Umakoshi, Y. Comparison of osteoblast responses to hydroxyapatite and hydroxyapatite/soluble calcium phosphate composites. J. Biomed. Mater. Res. A 2005, 72, 127-135. [CrossRef] [PubMed]

23. Yamada, S.; Heymann, D.; Bouler, J.M.; Daculsi, G. Osteoclastic resorption of calcium phosphate ceramics with different hydroxyapatite/beta-tricalcium phosphate ratios. Biomaterials 1997, 18, 1037-1041. [CrossRef]

24. Yao, C.-H.; Liu, B.-S.; Hsu, S.-H.; Chen, Y.-S.; Tsai, C.-C. Biocompatibility and biodegradation of a bone composite containing tricalcium phosphate and genipin crosslinked gelatin. J. Biomed. Mater. Res. A 2004, 69, 709-717. [CrossRef] [PubMed]

25. Daculsi, G. Biphasic calcium phosphate concept applied to artificial bone, implant coating and injectable bone substitute. Biomaterials 1998, 19, 1473-1478. [CrossRef]

26. Lobo, S.E.; Livingston Arinzeh, T. Biphasic Calcium Phosphate Ceramics for Bone Regeneration and Tissue Engineering Applications. Materials 2010, 3, 815-826. [CrossRef]

27. Jeong, J.; Kim, J.H.; Shim, J.H.; Hwang, N.S.; Heo, C.Y. Bioactive calcium phosphate materials and applications in bone regeneration. Biomater. Res. 2019, 23, 4. [CrossRef]

28. Helder, M.N.; van Esterik, F.A.S.; Kwehandjaja, M.D.; ten Bruggenkate, C.M.; Klein-Nulend, J.; Schulten, E.A.J.M. Evaluation of a new biphasic calcium phosphate for maxillary sinus floor elevation: Micro-CT and histomorphometrical analyses. Clin. Oral Implants Res. 2018, 29, 488-498. [CrossRef]

29. Ebrahimi, M.; Botelho, M.G.; Dorozhkin, S.V. Biphasic calcium phosphates bioceramics (HA/TCP): Concept, physicochemical properties and the impact of standardization of study protocols in biomaterials research. Mater. Sci. Eng. C Mater. Biol. Appl. 2017, 71, 1293-1312. [CrossRef]

30. Liu, B.; Gao, X.; Sun, Z.; Fang, Q.; Geng, X.; Zhang, H.; Wang, G.; Dou, Y.; Hu, P.; Zhu, K.; et al. Biomimetic porous silk fibroin/biphasic calcium phosphate scaffold for bone tissue regeneration. J. Mater. Sci. Mater. Med. 2018, 30, 4. [CrossRef]

31. Salerno, A.; Cesarelli, G.; Pedram, P.; Netti, P.A. Modular Strategies to Build Cell-Free and Cell-Laden Scaffolds towards Bioengineered Tissues and Organs. J. Clin. Med. 2019, 8, 1816. [CrossRef] [PubMed]

32. Shahabipour, F.; Ashammakhi, N.; Oskuee, R.K.; Bonakdar, S.; Hoffman, T.; Shokrgozar, M.A.; Khademhosseini, A. Key components of engineering vascularized 3-dimensional bioprinted bone constructs. Transl. Res. 2019. [CrossRef] [PubMed]

33. Antoniades, H.N.; Scher, C.D.; Stiles, C.D. Purification of human platelet-derived growth factor. Proc. Natl. Acad. Sci. USA 1979, 76, 1809-1813. [CrossRef] [PubMed]

34. Heldin, C.H.; Westermark, B.; Wasteson, A. Platelet-derived growth factor: Purification and partial characterization. Proc. Natl. Acad. Sci. USA 1979, 76, 3722-3726. [CrossRef] [PubMed]

35. Caplan, A.I.; Correa, D. PDGF in bone formation and regeneration: New insights into a novel mechanism involving MSCs. J. Orthop. Res. 2011, 29, 1795-1803. [CrossRef]

36. Jin, Y.; Zhang, W.; Liu, Y.; Zhang, M.; Xu, L.; Wu, Q.; Zhang, X.; Zhu, Z.; Huang, Q.; Jiang, X. rhPDGF-BB via ERK pathway osteogenesis and adipogenesis balancing in ADSCs for critical-sized calvarial defect repair. Tissue Eng. Part A 2014, 20, 3303-3313. [CrossRef]

37. Xu, L.; Lv, K.; Zhang, W.; Zhang, X.; Jiang, X.; Zhang, F. The healing of critical-size calvarial bone defects in rat with rhPDGF-BB, BMSCs, and beta-TCP scaffolds. J. Mater. Sci. Mater. Med. 2012, 23, 1073-1084. [CrossRef]

38. Moore, D.C.; Ehrlich, M.G.; McAllister, S.C.; Machan, J.T.; Hart, C.E.; Voigt, C.; Lesieur-Brooks, A.M.; Weber, E.W. Recombinant human platelet-derived growth factor-BB augmentation of new-bone formation in a rat model of distraction osteogenesis. J. Bone Jt. Surg. Am. 2009, 91, 1973-1984. [CrossRef]

39. Al-Zube, L.; Breitbart, E.A.; O'Connor, J.P.; Parsons, J.R.; Bradica, G.; Hart, C.E.; Lin, S.S. Recombinant human platelet-derived growth factor BB (rhPDGF-BB) and beta-tricalcium phosphate/collagen matrix enhance fracture healing in a diabetic rat model. J. Orthop. Res. 2009, 27, 1074-1081. [CrossRef]

40. DiGiovanni, C.W.; Lin, S.S.; Baumhauer, J.F.; Daniels, T.; Younger, A.; Glazebrook, M.; Anderson, J.; Anderson, R.; Evangelista, P.; Lynch, S.E. Recombinant human platelet-derived growth factor-BB and beta-tricalcium phosphate (rhPDGF-BB/ $\beta$-TCP): An alternative to autogenous bone graft. J. Bone Jt. Surg. Am. 2013, 95, 1184-1192. [CrossRef] 
41. Xie, H.; Cui, Z.; Wang, L.; Xia, Z.; Hu, Y.; Xian, L.; Li, C.; Xie, L.; Crane, J.; Wan, M.; et al. PDGF-BB secreted by preosteoclasts induces angiogenesis during coupling with osteogenesis. Nat. Med. 2014, 20, 1270-1278. [CrossRef] [PubMed]

42. Yancopoulos, G.D.; Davis, S.; Gale, N.W.; Rudge, J.S.; Wiegand, S.J.; Holash, J. Vascular-specific growth factors and blood vessel formation. Nature 2000, 407, 242-248. [CrossRef] [PubMed]

43. Zhang, M.; Yu, W.; Niibe, K.; Zhang, W.; Egusa, H.; Tang, T.; Jiang, X. The Effects of Platelet-Derived Growth Factor-BB on Bone Marrow Stromal Cell-Mediated Vascularized Bone Regeneration. Stem Cells Int. 2018, 2018, 3272098. [CrossRef] [PubMed]

44. Wöltje, M.; Böbel, M.; Bienert, M.; Neuss, S.; Aibibu, D.; Cherif, C. Functionalized silk fibers from transgenic silkworms for wound healing applications: Surface presentation of bioactive epidermal growth factor. J. Biomed. Mater. Res. A 2018, 106, 2643-2652. [CrossRef]

45. Sumida, M.; Ueda, H. Dietary sucrose suppresses midgut sucrose activity in germfree fifth instar larvae of the silkworm, Bombyx mori. J. Insect Biotechnol. Sericol. 2007, 76, 31-37.

46. Cappellozza, L.; Cappellozza, S.; Saviane, A.; Sbrenna, G. Artificial diet rearing system for the silkworm Bombyx mori (Lepidoptera: Bombycidae): Effect of vitamin C deprivation on larval growth and cocoon production. Appl. Entomol. Zool. 2005, 40, 405-412. [CrossRef]

47. Wöltje, M.; Böbel, M.; Rheinnecker, M.; Tettamanti, G.; Franzetti, E.; Saviane, A.; Cappellozza, S. Transgenic protein production in silkworm silk glands requires cathepsin and chitinase of Autographa californica multicapsid nucleopolyhedrovirus. Appl. Microbiol. Biotechnol. 2014, 98, 4571-4580. [CrossRef]

48. Rheinnecker, M.; Kohlhaas, S.; Zimmat, R. Method and apparatus for extraction of arthropod gland. U.S. Patent US 8,105,633 B2, 31 January 2012.

49. Hild, M.; Brünler, R.; Jäger, M.; Laourine, E.; Scheid, L.; Haupt, D.; Aibibu, D.; Cherif, C.; Hanke, T. Net Shape Nonwoven: A novel technique for porous three-dimensional nonwoven hybrid scaffolds. Text. Res. J. 2014, 84, 1084-1094. [CrossRef]

50. Brünler, R.; Hausmann, R.; von Münchow, M.; Aibibu, D.; Cherif, C. Design of Complexly Graded Structures inside Three-Dimensional Surface Models by Assigning Volumetric Structures. J. Healthc. Eng. 2019, 2019, 6074272. [CrossRef]

51. Brünler, R.; Aibibu, D.; Wöltje, M.; Anthofer, A.-M.; Cherif, C. In silico modeling of structural and porosity properties of additive manufactured implants for regenerative medicine. Mater. Sci. Eng. C Mater. Biol. Appl. 2017, 76, 810-817. [CrossRef]

52. Hajimiri, M.; Shahverdi, S.; Kamalinia, G.; Dinarvand, R. Growth factor conjugation: Strategies and applications. J. Biomed. Mater. Res. A 2015, 103, 819-838. [CrossRef] [PubMed]

53. Chen, G.; Ito, Y. Gradient micropattern immobilization of EGF to investigate the effect of artificial juxtacrine stimulation. Biomaterials 2001, 22, 2453-2457. [CrossRef]

54. Stefonek, T.J.; Masters, K.S. Immobilized gradients of epidermal growth factor promote accelerated and directed keratinocyte migration. Wound Repair Regen. 2007, 15, 847-855. [CrossRef] [PubMed]

55. Renders, G.A.P.; Mulder, L.; van Ruijven, L.J.; van Eijden, T.M.G.J. Porosity of human mandibular condylar bone. J. Anat. 2007, 210, 239-248. [CrossRef] [PubMed]

56. Gomez, S.; Vlad, M.D.; Lopez, J.; Fernandez, E. Design and properties of 3D scaffolds for bone tissue engineering. Acta Biomater. 2016, 42, 341-350. [CrossRef] [PubMed]

57. Jones, A.C.; Arns, C.H.; Sheppard, A.P.; Hutmacher, D.W.; Milthorpe, B.K.; Knackstedt, M.A. Assessment of bone ingrowth into porous biomaterials using MICRO-CT. Biomaterials 2007, 28, 2491-2504. [CrossRef]

58. Mastrogiacomo, M.; Scaglione, S.; Martinetti, R.; Dolcini, L.; Beltrame, F.; Cancedda, R.; Quarto, R. Role of scaffold internal structure on in vivo bone formation in macroporous calcium phosphate bioceramics. Biomaterials 2006, 27, 3230-3237. [CrossRef]

59. Karageorgiou, V.; Kaplan, D. Porosity of 3D biomaterial scaffolds and osteogenesis. Biomaterials 2005, 26, 5474-5491. [CrossRef]

60. Mosekilde, L.; Danielsen, C.C. Biomechanical competence of vertebral trabecular bone in relation to ash density and age in normal individuals. Bone 1987, 8, 79-85. [CrossRef] 
61. Lotz, J.C.; Gerhart, T.N.; Hayes, W.C. Mechanical properties of trabecular bone from the proximal femur: A quantitative CT study. J. Comput. Assist. Tomogr. 1990, 14, 107-114. [CrossRef]

62. Misch, C.E.; Qu, Z.; Bidez, M.W. Mechanical properties of trabecular bone in the human mandible: Implications for dental implant treatment planning and surgical placement. J. Oral Maxillofac. Surg. 1999, 57, 700-706. [CrossRef]

63. Pecqueux, F.; Tancret, F.; Payraudeau, N.; Bouler, J.M. Influence of microporosity and macroporosity on the mechanical properties of biphasic calcium phosphate bioceramics: Modelling and experiment. J. Eur. Ceram. Soc. 2010, 30, 819-829. [CrossRef]

64. Kim, D.-H.; Kim, K.-L.; Chun, H.-H.; Kim, T.-W.; Park, H.-C.; Yoon, S.-Y. In vitro biodegradable and mechanical performance of biphasic calcium phosphate porous scaffolds with unidirectional macro-pore structure. Ceram. Int. 2014, 40, 8293-8300. [CrossRef]

65. Park, S.A.; Lee, S.J.; Seok, J.M.; Lee, J.H.; Kim, W.D.; Kwon, I.K. Fabrication of 3D Printed PCL/PEG Polyblend Scaffold Using Rapid Prototyping System for Bone Tissue Engineering Application. J. Bionic Eng. 2018, 15, 435-442. [CrossRef]

66. Almirall, A.; Larrecq, G.; Delgado, J.A.; Martínez, S.; Planell, J.A.; Ginebra, M.P. Fabrication of low temperature macroporous hydroxyapatite scaffolds by foaming and hydrolysis of an alpha-TCP paste. Biomaterials 2004, 25, 3671-3680. [CrossRef]

67. Lopez-Heredia, M.A.; Sariibrahimoglu, K.; Yang, W.; Bohner, M.; Yamashita, D.; Kunstar, A.; van Apeldoorn, A.A.; Bronkhorst, E.M.; Félix Lanao, R.P.; Leeuwenburgh, S.C.G.; et al. Influence of the pore generator on the evolution of the mechanical properties and the porosity and interconnectivity of a calcium phosphate cement. Acta Biomater. 2012, 8, 404-414. [CrossRef]

68. Fuchs, S.; Ghanaati, S.; Orth, C.; Barbeck, M.; Kolbe, M.; Hofmann, A.; Eblenkamp, M.; Gomes, M.; Reis, R.L.; Kirkpatrick, C.J. Contribution of outgrowth endothelial cells from human peripheral blood on in vivo vascularization of bone tissue engineered constructs based on starch polycaprolactone scaffolds. Biomaterials 2009, 30, 526-534. [CrossRef]

69. Melero-Martin, J.M.; de Obaldia, M.E.; Kang, S.-Y.; Khan, Z.A.; Yuan, L.; Oettgen, P.; Bischoff, J. Engineering robust and functional vascular networks in vivo with human adult and cord blood-derived progenitor cells. Circ. Res. 2008, 103, 194-202. [CrossRef]

70. Rouwkema, J.; Westerweel, P.E.; de Boer, J.; Verhaar, M.C.; van Blitterswijk, C.A. The use of endothelial progenitor cells for prevascularized bone tissue engineering. Tissue Eng. Part A 2009, 15, 2015-2027. [CrossRef]

71. Dohle, E.; El Bagdadi, K.; Sader, R.; Choukroun, J.; James Kirkpatrick, C.; Ghanaati, S. Platelet-rich fibrin-based matrices to improve angiogenesis in an in vitro co-culture model for bone tissue engineering. J. Tissue Eng. Regen. Med. 2018, 12, 598-610. [CrossRef]

72. Unger, R.E.; Ghanaati, S.; Orth, C.; Sartoris, A.; Barbeck, M.; Halstenberg, S.; Motta, A.; Migliaresi, C.; Kirkpatrick, C.J. The rapid anastomosis between prevascularized networks on silk fibroin scaffolds generated in vitro with cocultures of human microvascular endothelial and osteoblast cells and the host vasculature. Biomaterials 2010, 31, 6959-6967. [CrossRef] [PubMed]

73. Unger, R.E.; Peters, K.; Wolf, M.; Motta, A.; Migliaresi, C.; Kirkpatrick, C.J. Endothelialization of a non-woven silk fibroin net for use in tissue engineering: Growth and gene regulation of human endothelial cells. Biomaterials 2004, 25, 5137-5146. [CrossRef] [PubMed]

74. Fuchs, S.; Jiang, X.; Schmidt, H.; Dohle, E.; Ghanaati, S.; Orth, C.; Hofmann, A.; Motta, A.; Migliaresi, C.; Kirkpatrick, C.J. Dynamic processes involved in the pre-vascularization of silk fibroin constructs for bone regeneration using outgrowth endothelial cells. Biomaterials 2009, 30, 1329-1338. [CrossRef] [PubMed]

75. Farokhi, M.; Mottaghitalab, F.; Samani, S.; Shokrgozar, M.A.; Kundu, S.C.; Reis, R.L.; Fatahi, Y.; Kaplan, D.L. Silk fibroin/hydroxyapatite composites for bone tissue engineering. Biotechnol. Adv. 2018, 36, 68-91. [CrossRef] [PubMed]

76. Mandal, B.B.; Kundu, S.C. Osteogenic and adipogenic differentiation of rat bone marrow cells on non-mulberry and mulberry silk gland fibroin 3D scaffolds. Biomaterials 2009, 30, 5019-5030. [CrossRef] [PubMed]

77. Mauney, J.R.; Nguyen, T.; Gillen, K.; Kirker-Head, C.; Gimble, J.M.; Kaplan, D.L. Engineering adipose-like tissue in vitro and in vivo utilizing human bone marrow and adipose-derived mesenchymal stem cells with silk fibroin 3D scaffolds. Biomaterials 2007, 28, 5280-5290. [CrossRef] 
78. Jung, S.-R.; Song, N.-J.; Yang, D.K.; Cho, Y.-J.; Kim, B.-J.; Hong, J.-W.; Yun, U.J.; Jo, D.-G.; Lee, Y.M.; Choi, S.Y.; et al. Silk proteins stimulate osteoblast differentiation by suppressing the Notch signaling pathway in mesenchymal stem cells. Nutr. Res. 2013, 33, 162-170. [CrossRef] [PubMed]

79. Hilton, M.J.; Tu, X.; Wu, X.; Bai, S.; Zhao, H.; Kobayashi, T.; Kronenberg, H.M.; Teitelbaum, S.L.; Ross, F.P.; Kopan, R.; et al. Notch signaling maintains bone marrow mesenchymal progenitors by suppressing osteoblast differentiation. Nat. Med. 2008, 14, 306-314. [CrossRef]

C 2019 by the authors. Licensee MDPI, Basel, Switzerland. This article is an open access article distributed under the terms and conditions of the Creative Commons Attribution (CC BY) license (http://creativecommons.org/licenses/by/4.0/). 